\title{
Flipping the classroom: developing teaching skills for future in-service english teachers
}

\section{Volteando el aula: desarrollo de habilidades de enseñanza para futuros maestros de inglés en servicio}

\author{
Heidi Marlen Marriott Toledo \\ Universidad de Guayaquil, Ecuador \\ Universidad Internacional del Ecuador, Ecuador \\ Lucila Margarita Sánchez Pérez \\ Universidad de Guayaquil, Ecuador
}

Autor para correspondencia: heidi.marriottt@ug.edu.ec, hemarriottto@internacional.edu.ec, lucila.sanchezp@ug.edu.ec

Fecha de recepción: 25 de Mayo de 2017 - Fecha de aceptación: 10 de Mayo de 2017

Resumen: Los futuros docentes del idioma inglés como lengua extranjera deben ser equipados no sólo la proficiencia linguística del estudiante sino también las destrezas necesarias para afrontar el desafío de alcanzar altos niveles de motivación y desempeño académico entre sus estudiantes, quienes son considerados nativos digitales; desafíos que encontrarán en las aulas de clase del siglo 21. Dichas destrezas pueden ser desarrolladas a través de la aplicación del modelo de clase invertida durante sus estudios de pre-grado, razón por la cual el presente trabajo investigativo busca explorar diferentes estrategias que pueden ser empleadas para enlazar teorías; tales como, las inteligencias múltiples el aprendizaje a niveles superiores y el desarrollo del pensamiento crítico, todo ello combinado con el uso de la tecnología dentro y fuera del aula de clases. Se presta especial atención a la adaptación de la instrucción acorde a las necesidades e intereses de los estudiantes, a los diferentes niveles de proficiencia en el idioma Inglés, y a la promoción de la zona próxima de desarrollo con el fin de ser incorporados al modelo de Clase Invertida. De ésta forma los futuros docentes aprenderán a través de la experiencia y podrán aplicar con mayor facilidad dicho modelo como una práctica efectiva de enseñanza - aprendizaje con sus educandos.

Palabras Clave: clase invertida; estudiantes pregrado; enseñanza de inglés como lengua extranjera; aprendizaje de inglés

Abstract: In teaching English as a foreign language (EFL) to future in-service teachers, instructors need to develop not just the students' language proficiency, but also the necessary skills for $21^{\text {st }}$ century teaching in the ever changing classroom where pupils are considered as digital natives. The required skills future teachers need to accomplish, a higher level in both the students' performance and class interest, can be developed through the Flipped classroom model, which is why this research work aims to explore diverse strategies that can be applied to blend theories such as multiple intelligences and higher order thinking in order to develop students' critical thinking skills through the incorporation of technology outside and inside the classroom. Considerations to differentiated instruction (DI), students' different levels of Second Language Acquisition (SLA), and the fostering of the Zone of proximal development (ZPD) of learners are also given as a feature 
that needs to be incorporated in flipped classrooms. In real-to-life teaching practice, this offers students the possibility to incorporate effective practices that can be directly applied in their future classrooms.

Key words: flipped classroom; undergraduate students; EFL teaching; English learning

\section{Introduction}

Technology has changed the human life in all aspects and education is not an exception. In 2000 The American Council on Education stated "the growth of the Internet coupled with a growing demand for convenient and flexible access to higher education have brought about the greatest change in education delivery since the first correspondence courses were made available in the early nineteenth century" (as mentioned by Lehmann, 2004); this prediction has come true and it is a reality inside our classrooms. Our students are digital natives, they are familiarized with the use of the Internet and all kind of digital devices because they are surrounded by technology since the moment they are born (Presnky, 2001).

The digital generation has also a huge impact in teacher's instruction and the way how it should be delivered. Teachers should be aware that due to the fact that because of the "upbringing and experiences with technology, digital natives have particular learning preferences or styles that differ from earlier generations of students" (Bennet, Maton, \& Kervin, 2007). The twenty-first century teacher should seek the development of students' critical thinking skills, the application of differentiated instruction to cater to students' individual needs, and the incorporation of technology to the class in order to prepare learners to be successful in their current and future lives. The teaching of English as a foreign language (EFL) also has to prepare future in-service teachers to match this reality by incorporating these instructional features as effective teaching practices for their future classrooms. This creates a need for EFL instructors to not only work on future in-service teachers language proficiency, but also work on the development of teaching skills that incorporate the use of technology in class delivery in order to meet digital native learning needs; thus, making the implementation of flipped classroom in this area worthy of consideration.

\section{Flipped Classroom}

The pioneers of this teaching model were two teachers from a high school in Woodland Park CO, United States of America. Jonathan Bergman and Aaron Sams were concerned about students who missed classes in order to attend sports competitions or other events. For that reason, they decided to record their Chemistry lectures by using screen capture software that were later uploaded as videos to YouTube. In this way, their students could download the lectures and watch them at home whenever they wanted and as many times they needed it. The students were benefitted with a better understanding of the content. Since 2007, this teaching model has been applied by many teachers around the world. (flippedclass, 2011)

A flipped classroom is defined as a class where "students are required to use web resources as homework and undertake initial instruction of the lesson content themselves on new topics, while the class time is used for interesting laboratory explorations or practice activities using the new content" (Bender \& Waller, 2013, p. 80). In other words the traditional model where the teacher explains the new content to the students inside the classroom and gives reinforcement tasks 
to be developed at home is changed for a model where the teacher becomes a facilitator of learning by monitoring classroom activities and by reinforcing and building upon the concepts that the students have already reviewed at home. The leaders of the Flipped Learning Network (FLN) highlight the difference between flipped classroom and flipped learning. They state that teachers can flip their classroom by sending students to read at home or watch educational videos but it does not necessarily means that the learning is being flipped. FLN states that a flipped learning should be based in the four pillars of F-L-I-P "flexible environment, learning culture, intentional content, and professional educator" (Flipped Learning Network, 2014)

The first pillar flexible environment involves differentiated instruction through considering our students learning styles and multiple intelligences during the instruction and assessment. The second pillar is the learning culture which considers the student as the center of the instruction. This pillar is based on the constructivist approach for that reason the classroom time is used for students to analyze the topic in depth and to work with the teacher and partners to understand and take ownership of the content in meaningful ways. The third pillar is the intentional content. It guides the teacher to decide which content should be taught in the classroom and which content can be managed by students at home. Finally, the fourth pillar is the need of professional educators. It involves the critical reflection from the teacher of his teaching practice. It is the sharing of educational strategies with other teachers and the acceptance of criticism in order to improve instructional practice. It is the searching of teaching tools that best fit their students' needs. (Hamdan, McKnight, McKnight, \& Arfstrom, 2013) . In other words, flipped classroom and flipped learning are correlated but they are not considered interchangeable terms.

\section{Literature Review}

Despite the fact that this teaching model is innovative the research done so far demonstrates the effectiveness of using flipped classroom in teaching different subjects. Schwankl (2013) conducted a study to measure the effects on achievement and students perception of flipped classroom in a rural southwestern Minnesota school. The sample involved two groups, one control and one treatment group. The students were enrolled in Integrated II Mathematics classes. The participants were freshman and sophomores students and one junior student. The researchers applied pre-tests and post-tests to both groups. The treatment group received classes by applying flipped classroom model; the teachers recorded the lectures by using Screencast-O-matic and then they uploaded the videos on Youtube, the teachers also gave the students the option to access to the recorded lectures by using a flash memory. The students were required to watch the videos at home and develop assignments and learning activities during the classroom's time. The control group received classes by using the traditional instruction. Both groups studied the same content during the research period. The total score in the post-tests reflected a higher achievement of the treatment group (5.54\%) over the control group $(1.81 \%)$.

Pearson (2013) reports how the flipped learning model dramatically improves course approval rates for at-risk students in the Clintondale High School in Clinton Township, Michigan in United States of America. The participants were 32 teachers and 553 students. In 2010, the high school implemented Flipped Classroom for teaching Math, Science, Social Studies, and English Language arts to freshman at-risk students. The teachers created videos of their 
classroom lectures and posted them online in order to the students watched the videos at home as homework; the classroom's time was used for educators to work with students on individual tasks and to foster collaborative learning through small groups tasks related with the content studied by the students at home. The results showed that by the end of the first semester of implementing this teaching model the pass rate increased in Math from 56\% to 69\%; in Science from 59\% to 78\%; in Social Studies from $72 \%$ to $81 \%$ and in English Language Arts from $48 \%$ to $67 \%$. In addition of these case studies more qualitative and anecdotal data can be found online as support of flipped classroom benefits for teachers and students.

For the aforementioned reasons, these studies prove the effectiveness of implementing flipped classrooms to achieve higher levels of students' performance and class interest.

\section{Application}

In order to apply flipped classroom as a teaching model for EFL instruction four aspects need to be considered: the sources, the homework, the activities developed by the students within the class time, and finally the assessment tools.

\section{Sources}

When EFL teachers think in the term flipped classroom the first thing that arises in their mind is technology. There are two main issues for future in-service teachers to consider regarding to technology. The first concern is the students' access to internet or technology itself. It is well known that in developing countries not all students have access to an internet connection at home which can make it difficult for learners to fulfill certain tasks assigned by teachers. On that regard, teachers should take special attention to enquire about students' technology access and ensure taking the necessary measures to overcome students' limitations to perform tasks; for instance, the use of flash memories can be enforced or the availability of computers during school time could be allocated.

The second issue is related to the teachers' struggle with technology. Despite the current importance given to technology in teaching, there is still a big group of teachers considered digital immigrants who still struggle with technology. Most of these teachers are afraid to use technology as part of their curriculum delivery because they think that it is demanding, stressful and difficult to handle. It is important to remark that it is not necessary to have high level tech knowledge to address a flipped classroom model. We can find online recording software or applications easy to handle. The easiest way is to record the lesson and upload it at Youtube. The video can be recorded by using Screencast-O-Matic which is a screen capture software, which is available for free to educators. This application gives teachers the option to record just their voice and explain what appears on the screen; educators can also include themselves on the screen by using a webcam. Educators can use websites, power point or any other tool to explain the content of the lesson to the students. When the recording is done teachers have the choice to publish the video to you tube or to publish a video file; the second one allows teacher to save the video on their computer in the format that they choose in this way the students have the opportunity to access to the videos by using internet or by saving the video in a flash memory to be watched at home. (Reardon, 2014). 


\section{Homework}

According to Bergmann and Sams (2012) educators should observe four stages for making the videos that students will watch at home as homework. Those stages are: Planning the lesson, recording the video, editing the video, and publishing the video.

Planning the lesson. Teachers should plan the lesson as they usually do before starting with the recording, it is crucial to "determine the objective of your lesson and decide whether a video is an appropriate instructional tool to accomplish the educational goal of the lesson" (Bergmann \& Sams, 2012). Teachers have to use practical wisdom to choose the videos and the content of the videos that best fit with the target of the lesson and the National Curriculum Standards.

Recording the video. Teachers have to avoid overacting in front of the webcam. The instruction should be in the same way as he was in front of the class. It is advisable to record the lessons in a more conversational style rather than formal style because it will foster the students' engagement. (Bergmann \& Sams, 2012)

Editing the video. This step can be time consuming but it is necessary because during this process teachers can add more information or take out irrelevant information from the video. The objective is to "highlight and reinforce what has been said in the recording with a visual cue that can aid in students understanding”. (Bergmann \& Sams, 2012)

Publishing the video. One of the most accessible ways to publish a video would be to upload it to YouTube. In order to do this, teachers can open a YouTube account and give the students the link were they can view the videos. Another option would be saving the videos in a flash memory or to burn them on a DVD for students who do not have access to internet. The suggestion is "to pick one or two methods that meet the needs of your students and do them well" (Bergmann \& Sams, 2012)

As EFL teachers, flipped classroom offers us a world of possibilities by using free tools available online for teaching EFL students. These tools can easily meet the content of the lesson and our students' different learning styles for instance "videos can really be a good addition to any class, especially for students who may be struggling readers or those who are visual learners" (Arntsen, 2014). Visuals will help our students have a better understanding of the content. Tools that can be used for EFL teachers are available online, for example the Learn American English Online site offers students resources that include readings and tasks to improve English grammar and vocabulary acquisition. It includes content for different levels of Second Language Acquisition (SLA). According to Lowe (2014) "the website is a great resource in a "flipped classroom," because it allows students to preview a grammar point at home before coming to class to practice the use of the grammar in communicative activities". This preview grammar knowledge can be used to develop listening and speaking skills during the class time.

\section{Class Time Activities}


Flipped classroom is a student-centered model which is related with the differentiated instruction (DI) approach. DI allows teachers "to develop lesson plans and activities that keep children from being left behind or waiting to move on" (Heacox, 2012), it gives educators the opportunity to meet their students' needs. It takes into consideration the different levels of Bloom's taxonomy to promote the student's development of higher order thinking skills while also giving attention to the different multiple intelligences found in the classroom. In addition, flipped classrooms create a class ecology where the use of the Zone of Proximal Development (ZPD) theory becomes a main staple to foster students' scaffolding of knowledge.

According to Gardner (1983) there are eight ways in which people learn and he called them intelligences, they are: verbal/linguistic, logical/mathematical, visual/spatial, bodily/kinesthetic, musical, interpersonal, intrapersonal, naturalist and existential. (as mentioned by Garcia, 2004) Each one of these intelligences has different characteristics and EFL teachers can use diverse strategies in the class time to reinforce learning and monitor students' development of language skills. Some strategies are suggested in the table below.

Table 1 Multiple Intelligences Preferences and Strategies

\begin{tabular}{l|l}
\hline Intelligence Strength: & Students May Enjoy: \\
\hline Verbal-Linguistic & $\begin{array}{l}\text { Writing, speaking, publishing, vocabulary, } \\
\text { word puzzles, puns, tongue-twisters }\end{array}$ \\
\hline Logical-Mathematical & $\begin{array}{l}\text { Math games, logic puzzles, experiments, } \\
\text { codes, analogies, numbers, mysteries }\end{array}$ \\
\hline Visual-Spatial & $\begin{array}{l}\text { Maps, charts, diagrams, drawing, sculpture, } \\
\text { graphic organizers, models, puppets, } \\
\text { photographs }\end{array}$ \\
\hline Bodily-Kinesthetic & $\begin{array}{l}\text { Movement, dance, manipulatives, drama, } \\
\text { building, role-playing, sports }\end{array}$ \\
\hline Musical & $\begin{array}{l}\text { Musical instruments, listening, recording, } \\
\text { rhythmic language, poetry, songs, clapping }\end{array}$ \\
\hline Intrapersonal & $\begin{array}{l}\text { Board games, cooperative groups, } \\
\text { collective problem solving, interviewing, } \\
\text { peer tutoring, think-pair-share, discussions }\end{array}$ \\
\hline Naturalistic & $\begin{array}{l}\text { Joumaling, scrapbooks, reflection, goal- } \\
\text { setting, self-directed projects, debates, } \\
\text { memoir }\end{array}$ \\
\hline & $\begin{array}{l}\text { Outdoor experiences, plants, pets, bugs, } \\
\text { classifying natural objects, environmental } \\
\text { topics }\end{array}$ \\
\hline
\end{tabular}

Note: The data is from: "This Is Your Brain...This is Your Brain on Fire...Any Questions?” by Gray S, 2004. Retrieved from: http://teachers.yale.edu/curriculum/viewer/ initiative_09.06.06_u

Other strategies that can be used in class time are related to Bloom's Taxonomy of Educational Objectives (Bloom, 1984). Bloom presents different levels of thinking that students have to develop to reach meaningful learning. Using the flipped classroom model "tasks are 
scaffolded to align with Bloom's Taxonomy and build student understanding of the text" (Bretzmann, 2013). Each one of the levels assist learners in developing higher order thinking skills by doing class time assignments that encourage students to go beyond the prior knowledge they reviewed at home.

Figure 1 shows what levels are covered by the lesson videos (homework) and what levels should be covered in class time. EFL teachers can apply different strategies for incorporating Bloom's taxonomy in flipped classrooms, for instance students can work with graphic organizers for developing reading and comprehension skills.

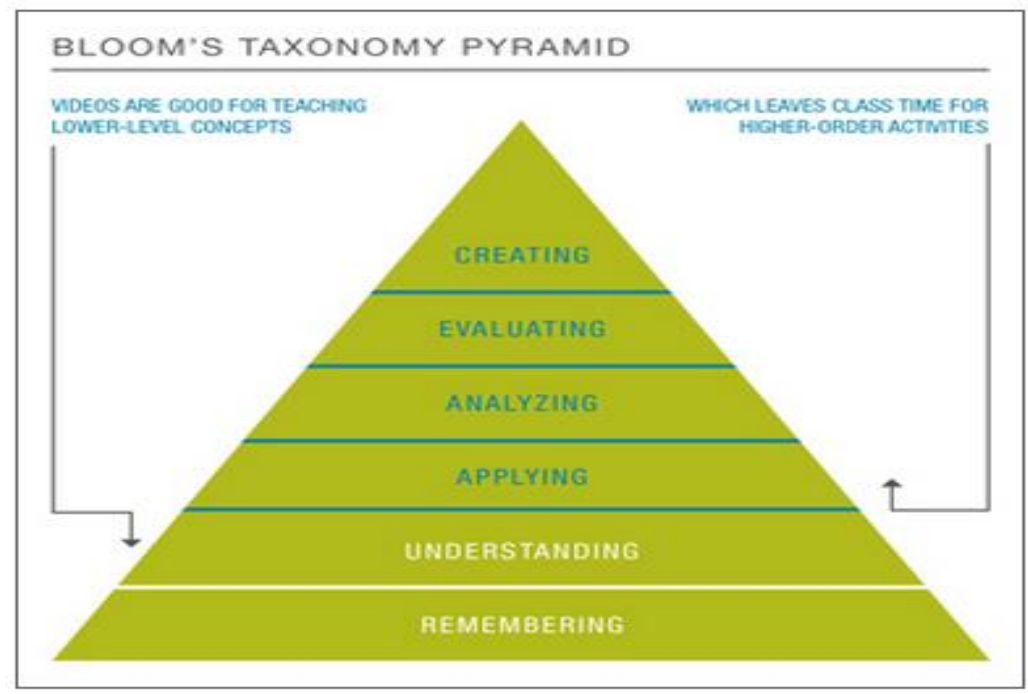

Figure 1. Bloom's Taxonomy Pyramid by Bergmann and Sams, 2014. Retrieved from https://www.iste.org/explore/articleDetail?articleid=14\&category=In-theclassroom\&article $=4+$ learning+strategies+that+make+the+most+of+flipped+learning

EFL teachers should also take notice of the activities that can be developed in each one of the thinking levels and different types of graphic organizers that can assist on reaching that level objectives. If the students have access to computers or iPads in the classroom educators can use online tools to create graphic organizers or visual products; a suggested free tool to be used is inspiration maps (http://www.inspiration.com/go/ipad).

EFL teachers are aware of the importance of interaction among students in order to develop language skills. Flipped classroom allows teachers to mostly use the class time to foster these interactions. The ZPD theory (Vygotsky, 1997) states that through collaborative learning people can understand content, they can achieve tasks and they can solve problems in a level that they would not be able to reach individually. Figure 2 explains the four stages of ZPD.

During class time teachers become a facilitator of learning by grouping students to accomplish a variety of activities and by monitoring the process and giving feedback and reinforcement when necessary. On their work Bergmann and Sams (2014) quote an anecdotal teacher's experience with flipped classrooms:

In traditional classroom, students spend the precious time they have with the teacher listening, as opposed to interacting. The flipped classroom flips the focus of the 
teacher to the students. I believe it offers students more down time to really practice, learn new concepts, and later on master them. (Bergmann \& Sams 2014).

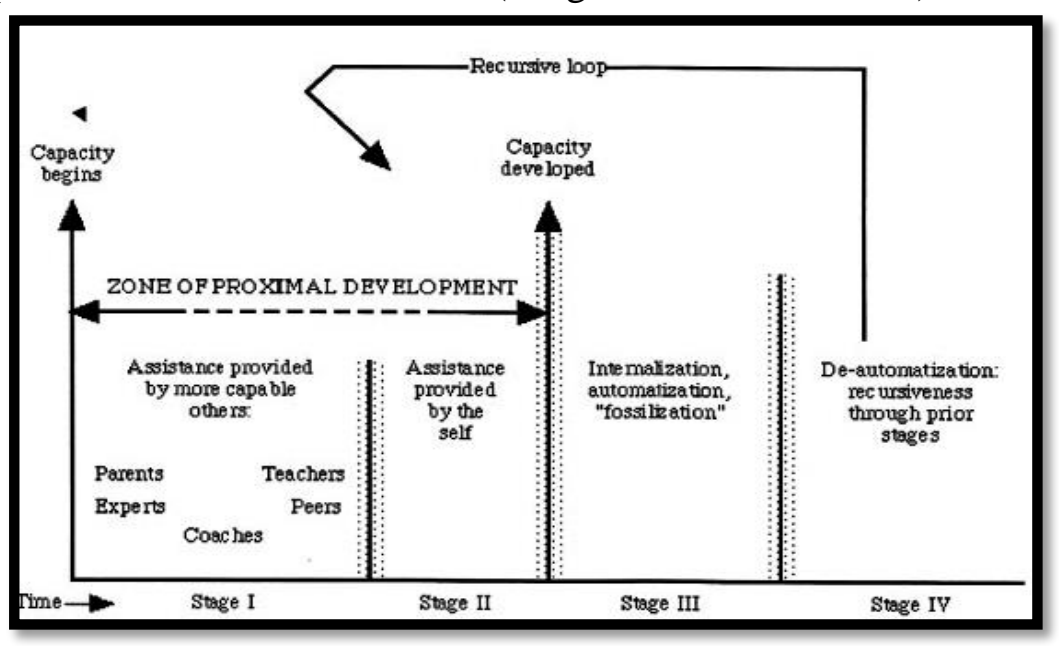

Figure 2. Model of four stages in the zone proximal development by Gallimore and Tharp, 1990.

\section{Assessment Tools}

Flipped classroom allows educators to apply formative assessment assigning in-class activities to students or assigning different activities to be accomplished out of class time. EFL teachers can develop assessment tools that blend the different levels of SLA with the diverse multiple intelligences. For instance to evaluate the students accuracy of applying new vocabulary words about the lesson "occupations", EFL educators can apply activities suggested in table 2.

The activities described can also be done by using technological tools if they are available for the students in classroom. The teacher can grade the assignment by applying rubrics which should be explained to the students in order to have a better understanding of the tasks' objective. The learners can choose what activity they will develop as assessment according to their English language level and learning preferences. Feedback can be send via email to the students and parents.

Table 2

Differentiating the Product

\begin{tabular}{|c|c|}
\hline Verbal/ Linguistic & Musical/ Rhythmic \\
\hline $\begin{array}{l}\text { Write an article about your favorite occupation to be } \\
\text { published in a magazine. }\end{array}$ & $\begin{array}{l}\text { Write a song from the point of view of your favorite } \\
\text { occupation }\end{array}$ \\
\hline Visual/ Spatial & Logical/Mathematical \\
\hline Do a story board about your favorite occupation. & $\begin{array}{l}\text { Design a game to show at least } 10 \text { different } \\
\text { occupations. }\end{array}$ \\
\hline Body/ Kinesthetic & Naturalist \\
\hline $\begin{array}{l}\text { Create a role play that involves the pros and cons of } \\
\text { your favorite occupation. }\end{array}$ & $\begin{array}{l}\text { Watch a video about occupations related with the } \\
\text { nature then write an article about it. }\end{array}$ \\
\hline Interpersonal & Intrapersonal \\
\hline
\end{tabular}


Create a TV show where you Interview to at least five Write an essay about what you like would to choose classmates about their favorite occupations. as your future occupation.

Note. Differentiating the Product by Sanchez L, 2015 unpublished manuscript, Kansas State University.

\section{Conclusion}

Technology has changed the traditional teaching and educators are conscious about this fact. Flipped classroom is starting to be a reality in classrooms everywhere and EFL future inservice teachers need to be ready to cater to the needs of highly digital learners through this novel teaching model. The benefits of flipping the classroom are many. It allows the opportunity to apply differentiated instruction that is palpable for students inside the classroom because the content is delivered at home and the class time is used for reinforcing and monitoring. Diverse strategies can be applied to blend students' multiple intelligences with the different levels of higher order thinking from Bloom's taxonomy. Also the teacher can differentiate the teaching by grouping the students in their different levels of SLA and by fostering the ZPD of the learners. Despite the fact that this teaching model is rather recent the research and the experience of many teachers support its application on different subjects. The results that can be achieved regarding students' motivation and performance make the flipped classroom model a tool worthy of consideration for teaching English as a foreign language.

\section{Bibliography}

Arntsen, T. (2014). educanon: for making videos interactive. Retrieved from blog.tesol.org: http://blog.tesol.org/educanon-for-making-videos-interactive/

Bender, W. N., \& Waller, L. B. (2013). Cool Tech Tools for Lower Tech Teachers: 20 tactics for every classroom. Thousand Oaks, California: Corwin.

Bennet, S., Maton, K., \& Kervin, L. (2007). onlinelibrary.wiley.com. Retrieved from http://onlinelibrary.wiley.com/doi/10.1111/j.1467-8535.2007.00793.x/epdf

Bergmann, J., \& Sams, A. (2012). Flip Your Classroom:Reach every student in every class every day. United States of America: International Society for Technology in Education.

Bergmann, J., \& Sams, A. (2014). 4 learning strategies that make the most of flipped learning. Retrieved from iste.org: https://www.iste.org/explore/articleDetail?articleid=14\&category=In-theclassroom\&article=4+learning+strategies+that+make+the+most+of+flipped+learning

Bergmann, J., \& Sams, A. (2014). Flipped Learning: Gateway To Student Engagement. United States of America: International Society for Technology in Education.

Bloom, B. (1984). Taxonomy of Educational Objectives: Book 1 Cognitive Domain. New York: Addison Wesley Longman.

Bretzmann, J. (Comp.).(2013). Flippin 2.0: Practical strategies for flipping your class. New Berlin, Wisconsin: The Bretzmann Group, LLC. 
Flipped Learning Network. (2014). Flipped Learning. Retrieved from http://flippedlearning.org/cms/lib07/VA01923112/Centricity/Domain/46/FLIP_handout _FNL_Web.pdf

flippedclass. (2011, may 6). flippedclass.com. Retrieved from http://flippedclass.com/the-historyof-the-flipped-class/

Gallimore, R., \& Tharp, R. (1990). Teaching mind in society: Teaching, schooling, and literate discourse. In LC Moll (ed). Vygotsky and Education: Instructional implications and applications of sociohistorical psychology. Cambridge: Cambridge University Press. .

Garcia, F. E. (2004). How Multiple Intelligences Theory Can Guide Teachers' Practices: Retrieved from urbanschools.org: http://www.urbanschools.org/pdf/onPOINTS.multiple.intelligences.DOCUMENT.style. LETTERSIZE.pdf

Gray, S. F. (n.d.). This Is Your Brain...This is Your Brain on Fire...Any Questions? Retrieved from teachersyale.edu: http://teachers.yale.edu/curriculum/viewer/initiative_09.06.06_u

Hamdan, N., McKnight, P., McKnight, K., \& Arfstrom, K. (2013). A Review of Flipped Learning. Retrieved from researchnetwork.pearson.com: http://researchnetwork.pearson.com/wpcontent/uploads/LitReview_2014_FlippedLearning_vFinal_JK_WEB.pdf

Heacox, D. (2012). Differentiating Instruction in the Regular Classroom: How to Reach and Teach All Learners. Minneapolis, MN: Free spirit.

Lehmann, K. J. (2004). How to be a great online teacher. Lanham, Maryland: Scarecrow Education.

Lowe, A. (2014). A Great Grammar Resource: Learn American English Online . Retrieved from blog.tesol.org: http://blog.tesol.org/a-great-grammar-resource-learnamericanenglish/

Pearson Education. (2013). Flipped Learning Model Dramatically Improves Course Pass Rate For At-Risk Students. Retrieved from assets.pearsonschool.com: http://assets.pearsonschool.com/asset_mgr/current/201317/Clintondale_casestudy.pdf

Prensky, M. (2001). marckprensky.com. $\quad$ Retrieved from http://www.marcprensky.com/writing/Prensky\%20-

\%20Digital\%20Natives, \%20Digital\%20Immigrants\%20-\%20Part1.pdf

Reardon, T. (2014). How to use Screen-O-Matic. Retrieved from www.kennesaw.edu: http://www.kennesaw.edu/elearning/2014tutorials/screencastomatic.pdf

Sanchez, L. (2015). Differentiating the Product. Unpublished manuscript. Kansas State University. 
Schwankl, R. (2013). Flipped classroom: Effects on achievement and student perception (Order No. 1523826). Retrieved from ProQuest Dissertations \& Theses Global: http://search.proquest.com.er.lib.k-state.edu/docview/1441947

Vygotsky, L. S. (1997). Interaction Between Learning and Development. In M. Gauvain, \& M. Cole, Readings on the Development of Children (pp. 29-35). New York: W.H. Freeman and Company. 